Hydrol. Earth Syst. Sci., 15, 2581-2597, 2011

www.hydrol-earth-syst-sci.net/15/2581/2011/

doi:10.5194/hess-15-2581-2011

(C) Author(s) 2011. CC Attribution 3.0 License.

\title{
The response of Iberian rivers to the North Atlantic Oscillation
}

\author{
J. Lorenzo-Lacruz ${ }^{1}$, S. M. Vicente-Serrano ${ }^{1}$, J. I. López-Moreno ${ }^{1}$, J. C. González-Hidalgo ${ }^{2}$, and E. Morán-Tejeda ${ }^{1}$ \\ ${ }^{1}$ Instituto Pirenaico de Ecología, CSIC (Spanish Research Council), Campus de Aula Dei, P.O. Box 202, \\ Zaragoza 50080, Spain \\ ${ }^{2}$ Departamento de Geografía, Universidad de Zaragoza, Spain
}

Received: 20 April 2011 - Published in Hydrol. Earth Syst. Sci. Discuss.: 5 May 2011

Revised: 29 July 2011 - Accepted: 16 August 2011 - Published: 24 August 2011

\begin{abstract}
In this study we analyzed the influence of the North Atlantic Oscillation (NAO) on the streamflow in 187 sub-basins of the Iberian Peninsula. Monthly and one-month lagged correlations were conducted to assess the spatiotemporal extent of the NAO influence on Iberian river discharges. Analysis of the persistence of the winter NAO throughout the year was also undertaken, together with analysis of streamflow anomalies during positive and negative NAO phases. Moving-window correlation analyses were conducted to assess potential changes in the temporal evolution of the NAO influence on Iberian streamflows. The results show that the NAO has a large impact on surface water resources throughout the Iberian Peninsula during winter, and in the Atlantic watershed during autumn. We showed that water resources management and snowmelt are causing the persistent dependence of streamflows on the previous winter NAO. We found that strongly positive streamflow anomalies occurred during winter, especially in the Atlantic watershed, and provide evidence of non-stationarity and spatial variability in the NAO influence on Iberian water resources.
\end{abstract}

\section{Introduction}

Numerous socioeconomic activities and ecological processes depend on the availability of adequate water resources. The demands for water by agriculture, tourism and industry are generally increasing, and this is resulting in extensive research into the processes that explain the spatiotemporal variability of climate and river flows (Bower et al., 2004; Kingston et al., 2006a). In addition to basin

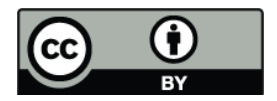

Correspondence to: J. Lorenzo-Lacruz (jlorenzo@ipe.csic.es) physiography, climate is the main factor explaining water yield (Krasovskaia et al., 1994), and consequently the study of climate forcing of surface water resources has become a key issue in hydrological research. In addition, study of the meteorological-hydrological relationships resulting from synoptic climatic patterns has been suggested to be important for understanding and predicting the behavior of river flows (e.g. Stahl and Demuth, 1999; Wilby, 2001; Bierkens and Van Beek, 2009). The interactions between river flow and low-frequency climate patterns have been studied in various hydrological systems worldwide. For example, studies have investigated the use of the El Niño-Southern Oscillation (ENSO) in forecasting river discharge variability in South America (Camilloni and Barros, 2000; Barros et al., 2004), the United States (Barlow et al., 2001; Bradbury et al., 2002; Brito-Castillo et al., 2003), Canada (Burn, 2008), India (Maity and Kumar, 2009), China (Xue et al., 2010) and elsewhere worldwide (Ward et al., 2010).

Several studies have demonstrated the occurrence of teleconnection patterns affecting the European climate, particularly in winter. These include the Eastern Mediterranean Teleconnection pattern (Hatzaki et al., 2007) and the Western Mediterranean Oscillation (WeMOi) (Martín-Vide and López-Bustins, 2006), which affect precipitation in the Mediterranean region. The dominant synoptic pattern in the European spatial context is the North Atlantic Oscillation (NAO) (Hurrell, 1995; Hurrel and Van Loon, 1997).

We focused on the NAO impacts on the streamflows of the Iberian Peninsula because it is widely recognized in hundreds of papers as the most influencing mode of variability affecting the climate in Western Europe. Moreover, we discarded El Niño-Southern Oscillation (ENSO) due to its weaker relationship with European precipitation; Atlantic multidecadal Oscillation (AMO) was not suitable to assess the interannual variability of streamflows since it is multidecadal; and finally Artic Oscillation $(\mathrm{AO})$ is a different way to describe the same

Published by Copernicus Publications on behalf of the European Geosciences Union. 
phenomenon that NAO does and they are very similar. In recent years there has been intensive study of the influence of the NAO on precipitation (Hurrell and Van-Loon, 1997; Rodriguez-Puebla et al., 1998; Uvo, 2003; Muñoz-Díaz and Rodrigo, 2004; López-Moreno and Vicente-Serrano, 2008), and its consequent effects on surface hydrology (Shorthouse and Arnell, 1997; Cullen et al., 2002; Rimbu et al., 2002; Kalayci and Kahya, 2006; López-Moreno et al., 2007; Massei et al., 2009; Morán-Tejeda et al., 2011).

The NAO is a circulation mode consisting of a north-south pressure dipole between temperate and high latitudes over the Atlantic Ocean (Hurrell, 1995; Hurrell et al., 2003). The largest amplitudes of NAO anomalies occur particularly during winter (Hurrell and Van-Loon, 1997), when the NAO controls the direction of the wind fields and the interactions between air masses in the North Atlantic region, which influences the weather and hydrology of the region (Hurrell et al., 2003; Kingston et al., 2006b). During positive NAO winters stronger than average westerly winds occur across middle latitudes of the Atlantic region, and intensification of the storm tracks towards northern Europe is common (Rodwell et al., 2002; Trigo et al., 2002). This synoptic configuration generates wetter (dryer) winters in northern (southern) Europe, whereas negative NAO phases have the opposite effect (Visbeck et al., 2001). Consequently, these patterns could affect the dynamics of European surface water resources, and their effects on surface hydrology are being widely explored. Streamflows in northern European rivers are generally positively correlated with the NAO, whereas streamflows in central and southern rivers show the opposite relationship. A positive and significant relationship $(r>0.6)$ was found during winter in Scandinavia (Shorthouse and Arnell, 1997), and similar values were found for river basins in Britain (Philips et al., 2003; Lavers et al. (2010). A significant negative relationship ( $r=-0.75$ ) was reported by Rimbu et al. (2002) for the Danube River in central Europe, and moderate negative correlations $(r \approx-0.4)$ have been reported (Pekarova and Pekar, 2004) for various sites in the Hron basin, Slovakia.

In the Mediterranean region a negative relationship between the NAO and river discharges has been found in the Middle East (Cullen and DeMenocal, 2000; Cullen et al., 2002) and in Turkey (Karabörk et al., 2005; Kalayci and Kahya, 2006), where lake levels have also been related to the NAO (Kücük et al., 2009). Within the Iberian Peninsula (hereafter IP) the influence of the NAO on river discharges has been analyzed in studies of various basins (LópezMoreno et al., 2007; Trigo et al., 2004; Morán-Tejeda et al., 2011), where reasonably high correlations have been found between the NAO and streamflows, particularly in winter. Nevertheless, there remain gaps in understanding of the nature of this relationship and its spatio-temporal variability, as recent studies (Beranová and Huth, 2008; Vicente-Serrano and López-Moreno, 2008) have shown a non-stationary influence of the NAO on the climate in Europe. Moreover, no studies have considered the IP as a whole, which is necessary to gain an understanding of the spatio-temporal dynamics of the relationship.

Water management in the IP is difficult because of the great variability of seasonal and annual flows (Iglesias et al., 2005; Lorenzo-Lacruz et al., 2010). This is a consequence of the high spatio-temporal variability of precipitation (Esteban-Parra et al., 1998; González-Hidalgo et al., 2001, 2009, 2010), which has raised research interest in using the NAO to forecast streamflow variability in the IP, and applying it in water management planning. Furthermore, the ability to predict water resources availability based on the lagged response of streamflows to the NAO (Trigo et al., 2004; López-Moreno et al., 2007) suggests this as a promising tool for optimizing water management in the IP. However, the non-stationary relationship between climate and the NAO in the northern hemisphere (Beranova and Huth, 2008; Vicente-Serrano and López-Moreno, 2008) must be further assessed and understood to advance the use of the NAO for predicting available water resources in particular basins.

This study addressed the research gap in understanding of the impacts of the NAO on streamflow variability in the IP as a whole, as analyses to date have been restricted to individual basins. We investigated the influence of the NAO on river discharges in 187 sub-basins belonging to 11 major basins within the IP. The objectives of the analysis were: (i) to quantify the impact of the NAO on streamflows over time; (ii) to establish the spatial distribution of this impact among different basins within the IP; (iii) to assess the persistence of the winter NAO influence on streamflows throughout the year; (iv) to quantify the streamflow anomalies occurring during extreme NAO phases, and in basins along the spatial gradient from west to east; and (v) to assess whether the NAO influence on surface water resources was stable or changed during the study period.

\section{Study area}

The IP encompasses $583254 \mathrm{~km}^{2}$ and has very contrasting and uneven relief. The mountain ranges of the IP are mainly distributed from west to east, and in some cases reach altitudes of approximately $3000 \mathrm{~m}$ a.s.l., resulting in the IP region having the second highest mean altitude (637 $\mathrm{m}$ a.s.1.) in western Europe. These ranges have conditioned the river network and the spatial configuration of the major basins for rivers flowing towards the Atlantic Ocean (the Miño, Duero, Tajo, Guadiana and Guadalquivir basins) and the Mediterranean Sea (the Segura, Júcar and Ebro basins) (see Fig. 1). The location and topography of the IP, together with the effects of large atmospheric circulation patterns (LópezBustins et al., 2008) have generated a northwest to southeast gradient in annual precipitation (De-Castro et al., 2005; González-Hidalgo et al., 2010) (see Fig. 1), which varies from less than $300 \mathrm{~mm} \mathrm{yr}^{-1}$ to more than $2000 \mathrm{~mm} \mathrm{yr}^{-1}$, 


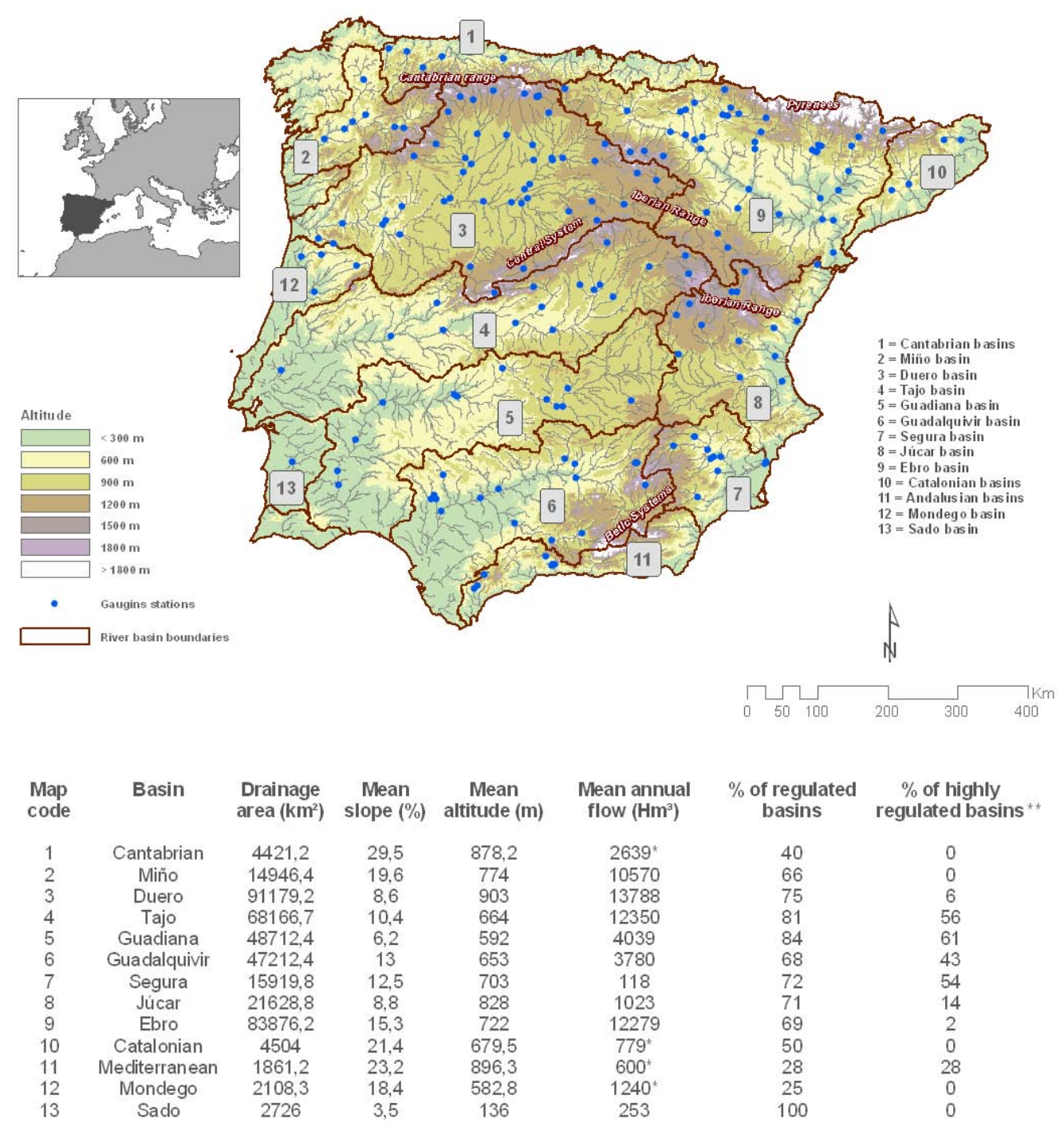

Fig. 1. Up: location of the 187 streamflow series for the period 1945-2005 used in the study. Down: Characteristics of the main river basins. Note that the streamflow is referred to the gauging station closest to the river mouth to the sea. * sum of the annual flows of all gauging stations belonging to the basin, since there are not a main course which accounts for the water yield of the whole basin. ** highly regulated basins include all basins with a mean annual discharge below its retention capacity.

and the precipitation is concentrated mainly in winter $(40 \%$ of annual precipitation). Basins in the northern sector of the Atlantic watershed (Miño, Duero and Tajo) yield abundant flows (mean annual contribution at the most downstream streamflow gauge: $10570 \mathrm{hm}^{3}$ for the Miño River, $13788 \mathrm{hm}^{3}$ for the Duero River, and $12350 \mathrm{hm}^{3}$ for the Tajo River), whereas rivers in the southern sector of the Atlantic watershed (Guadiana and Guadalquivir) have modest streamflows $\left(4039 \mathrm{hm}^{3}\right.$ and $3780 \mathrm{hm}^{3}$, respectively). Streamflows in basins in the Mediterranean watershed (Segura, Júcar and Ebro) are generally scarce; the exception is the Ebro basin, which receives abundant flow $\left(12279 \mathrm{hm}^{3}\right)$ that is generated in the Cantabrian Range and the Pyrenees.
The river flows and strong seasonality of precipitation have together created a marked imbalance between water availability and demand throughout the IP, and created the need for construction of a complex network of dams and channels to optimize use of the available water resources. This is especially the case for the southern basins, where significant regulation capacity has been generated in the last $60 \mathrm{yr}$ (Arroyo-Ilera, 2007). The intensive regulation of river systems in the IP is reflected in an increase in the number of major reservoirs constructed during the 20th century (from 58 in 1900 to 1195 in 2000), reaching a total storage capacity of $56500 \mathrm{hm}^{3}$ (Berga-Casafont, 2003). This capacity is approximately equal to the mean annual streamflow of the 8 major rivers of the IP $\left(55850 \mathrm{hm}^{3}\right)$. 


\section{Dataset and methodology}

\subsection{Hydrological data}

\subsubsection{Streamflow data}

To create a robust hydrological database for the entire IP, monthly streamflow data were obtained from four Spanish water agencies (Centro de Estudios Hidrográficos, Agència Catalana de l'Aigua, Agencia Andaluza del Agua and Augas de Galicia) and one Portuguese agency (Sistema Nacional de Informaçâo de Recursos Hídricos). The quality and length of the series were highly variable. For this reason, the criterion for selection of the series to be analyzed was based on a balance between the spatial density and the temporal coverage. A representative sample of the most important basins distributed across the entire IP was preferred, as was a temporal coverage of at least $50 \mathrm{yr}$. Consequently, the period of the monthly flow series was set from 1945 to 2005, with the aim of including in the analysis the effects of changes caused by the intensive regulation of rivers that took place in the second half of the 20th century. A total of 187 monthly streamflow series were selected based on the length and percentage of data gaps: only series with $<10 \%$ missing data were included. Gap filling was achieved by linear regression with the following criteria: series included in the regression model had to be derived from the same river or river system as the series to be filled, and the Pearson's correlation coefficient between the series had to be at least $R=0.8$.

\subsubsection{Standardization of streamflows}

To obtain a hydrological index that enabled comparison of streamflow series in time and space, regardless of the magnitudes and river regimes, we transformed the monthly streamflows series into standardized anomalies in $z$-scores. It is very common that hydrological series are not normally distributed, and must consequently be adjusted to other probability distributions (Gámiz-Fortis et al., 2010; VicenteSerrano et al., 2011). To achieve this the series were fitted to the most suitable probability distribution from among the general extreme value (GEV), the Pearson type III (PIII), the loglogistic, the lognormal, the generalized Pareto and the Weibull distributions, and a standardized streamflow index (SSI) was obtained. More details of the calculation of the SSIs are provided in Vicente-Serrano et al. (2011).

\subsection{North Atlantic Oscillation index}

Amongst the various approaches to calculation of the NAO index (Osborn et al., 1999; Pozo-Vázquez et al., 2000), we choose the procedure that involves the subtraction of the normalized level pressures of two different stations. We used the NAO index developed by Jones et al. (1997), who selected the Reykjavik and Gibraltar stations. The advantage of this index is the high negative correlations between the stations in winter (Qian et al., 2000), with the Gibraltar station being the most representative of the south dipole relative to other commonly used stations, including Ponta Delgada and Lisboa (Osborn et al., 1999). The NAO index data covering the study period (1945-2005) was obtained from the Climate Research Unit website (http://www.cru.uea.ac.uk/cru/data/nao/ nao.dat).

To assess the influence of the winter NAO on water resources throughout the year we calculated a winter NAO index as the average of the indexes for December in one year, and January, February and March in the following year. This enabled estimation of how the interaction between the most active NAO season (Castro-Díez et al., 2002; Muñoz-Díaz et al., 2004; López-Moreno et al., 2007; Vicente-Serrano et al., 2011) and other factors, including the intensive water regulation system of the IP and snowmelt processes (BergaCasafont, 2003; Arroyo-Ilera, 2007; Morán-Tejeda et al., 2011), conditioned water availability in subsequent months.

Extreme NAO episodes influencing streamflows were also assessed. For this we defined winter NAO records as extreme positive (negative) phases if they were higher (lower) than the long-term mean \pm one standard deviation. As a result, the years 1957, 1961, 1967, 1983, 1989, 1990, 1992, 1995 and 2000 were classified as extreme positive NAO years, and the years 1947, 1955, 1956, 1963, 1964, 1965, 1969, 1977, 1979 and 1996 were classified as extreme negative NAO years. Streamflow anomalies for positive and negative phases were calculated against the long-term average streamflows, and the significance of the differences between the anomalies found during positive and negative NAO phases were tested using the Wilcoxon-Mann Whitney test. The Wilcoxon Mann-Whitney test is based on ranks that do not require normally distributed samples. Before the use of this test, the assumption of the independence of the observations from both groups is required. In our case, the streamflow anomalies differences series are independent, since they are calculated based on the mean anomalies registered during different years, months and NAO extreme phases.

\subsection{Analysis}

\subsubsection{Assessment of the NAO influence}

To assess the impact of the NAO on surface water resources in the IP, monthly Pearson correlations between the NAO and the SSI were calculated for each gauging station. Prior to correlating the SSI series and the NAO index, we linearly de-trended the time series to take into account the autocorrelation. This approach minimized the influence of time series trend and multi-year to decadal signal variability on the strength and significance of the computed correlation and the deduced NAO predictability.

Correlations were conducted each month and with lags of one month. The reason for correlating the NAO and streamflows using temporal lags is based on the premise that a delay 
occurs between precipitation and runoff derived from physical processes such as snowmelt, interception, infiltration or the retention of flows in dams for hydropower generation (Trigo et al., 2004). Lagged correlations allowed assessment of whether the hydrological conditions in the IP are conditioned by the behavior of the NAO in previous months. Similarly, we also assessed the correlation between the winter NAO index and the following monthly SSIs until the next winter.

\subsubsection{Non-stationarity analysis}

To assess the non-stationariy influence of the NAO on Iberian streamflows we performed an analysis based on the use of moving-window correlations (Pearson's correlation coefficients) between the winter NAO and the March SSIs for every gauging station. The result of the first calculation (19451965) was assigned to the middle year of this interval (1955). The second calculation was based on the years 1946-1966, and the process was repeated up to the years 1985-2005.

\subsubsection{Identification of spatio-temporal patterns}

Because of the regional scale of the study we used a principal component analysis (PCA) to summarize the spatio-temporal variability of the streamflow anomalies detected during the positive and negative NAO phases at the monthly scale. To provide an estimate of where the NAO influence had remained stable and where it had changed, the same procedure was conducted with the 187 moving-window correlation series between the NAO and streamflows at the annual scale.

PCA (see review in Preisendorfer, 1988) is a procedure commonly used by hydrologists to analyze the spatiotemporal variability of streamflows (Kalayci and Kahya, 2006); it allows retention of the common features of the samples and identification of local particularities. The PCA can be performed in $\mathrm{S}$ or $\mathrm{T}$ modes. The $\mathrm{S}$ mode identifies regions in which the temporal variation of the hydrological variables has the same pattern. The $\mathrm{S}$ mode has been therefore used to identify general temporal patterns in streamflow series (the observatories are the variables, and the time observations are the cases). Using this approach we obtained an additional non-correlated set of variables that were the linear combinations (transformed by Varimax rotation; White et al., 1991) of the originals. The coefficients of such combinations are called loading factors, and represent the correlations of the principal component with each original variable. Using this procedure we were able to classify each gauging station into the resulting groups by mapping the "maximum loading factors". The criterion used to determine the number of significant Principal Components was the explained variance: for the selection of a new Principal Component it must explain more than $5 \%$ of the variance.

\section{Results}

\subsection{Monthly (lagged and non-laged) correlations of the NAO with streamflow}

Figure 2 shows the $R$ Pearson's correlation between the monthly SSIs and the monthly NAO index at each gauging station for the period 1945-2005. A clear spatio-temporal pattern was observed for the interaction, with significant negative correlations occurring throughout most of the IP during winter (December to March), with some spatial differences between months. In December, at the beginning of the season, only the Atlantic watershed and some Pyrenean subbasins are under the influence of the NAO. During January and February almost the entire IP is under the NAO influence, whereas in March the response of some rivers of the Tajo, Guadiana, Júcar an Segura basins to the NAO weaken. Nevertheless this relationship rapidly disappeared in spring. Positive correlations (mostly non-significant) were evident sporadically from April to July in the eastern part of the IP. In contrast to the transition from winter to spring, the transition from late summer to autumn was gradual, with moderate negative correlations $(R \approx-0.35)$ becoming evident again in northern Iberia in late summer and the beginning of autumn. In October the NAO influence was evident in the basins in the Atlantic watershed (the central and western parts of the IP) and the Pyrenean basins, configuring a similar NorthSouth difference than the one observed in March. During November the area under the influence of the NAO decreased and was confined to the southwest of the IP. At the beginning of winter there was a reinforcement of the NAO signal, and a clear west-east pattern emerged during December, with significant negative correlations in the west that reached the basins on the western side of the Cantabrian Range, the Iberian Range and the Betic systems, which divide the IP into the Atlantic and the Mediterranean watersheds. This spatial configuration broadly reflected the climatic signal derived from the NAO-precipitation interaction during winter, which is enhanced in the Atlantic watershed sub-basins.

Figure 3 shows the one-month lagged Pearson's correlations between the SSI for a particular month and the NAO index for the previous month. We also investigated the presence of longer lags (results not shown), but in all cases the correlations decreased from 1 lagged month. Slightly higher correlations $(R \approx-0.6)$ relative to the non-lagged correlations described above were observed during winter (from December to February), although the number of stations significantly correlated with the NAO decrease in the southern and central sectors at the beginning of the season. During spring the one-month lagged NAO signal disappeared throughout most of the study area; the exception was in the Duero basin, where significant correlations were still recorded during April and May. Non-significant positive correlations during summer were occasionally detected. The reinforced response of streamflows to the NAO in the previous 

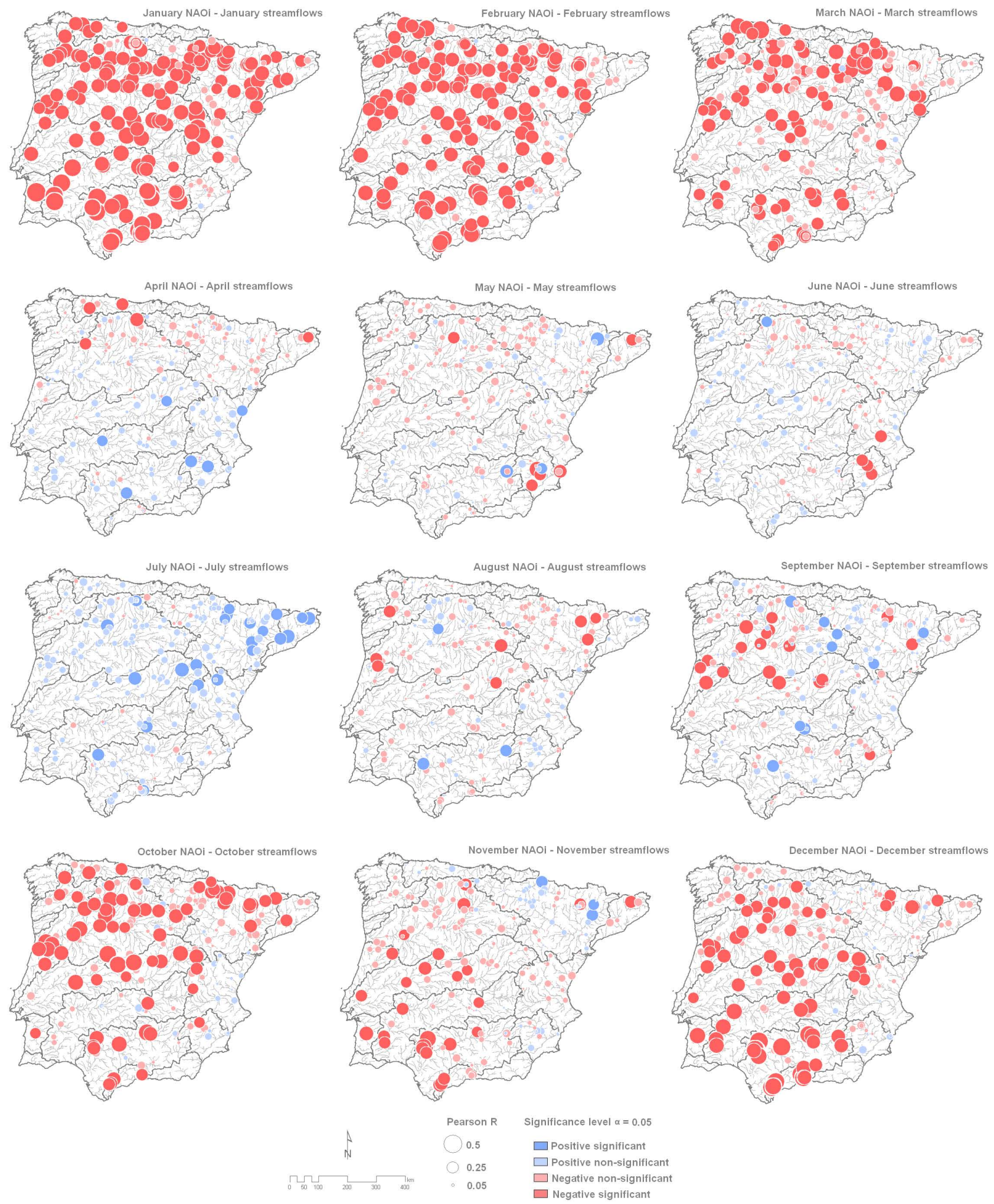

Fig. 2. Spatial distribution of the correlations between the monthly NAO index and the monthly SSI's. 
Table 1. Percentage of gauging stations which registered significant anomalies differences between positive and negative NAO phases.

\begin{tabular}{|c|c|c|c|c|c|c|c|c|c|c|c|c|}
\hline & Cantabrian & Miño & Duero & Tajo & Guadiana & Guadalquivir & Segura & Júcar & Ebro & Mondego & Catalonian & Andalusian \\
\hline Jan & 20 & 14 & 43 & 60 & 78 & 100 & 9 & 43 & 24 & 75 & 50 & 100 \\
\hline Feb & 60 & 71 & 74 & 93 & 100 & 100 & 18 & 64 & 52 & 75 & 50 & 100 \\
\hline Mar & 80 & 100 & 100 & 100 & 100 & 100 & 9 & 71 & 79 & 100 & 50 & 100 \\
\hline Apr & 20 & 71 & 71 & 100 & 100 & 75 & 18 & 57 & 48 & 75 & 50 & 57 \\
\hline May & 20 & 0 & 14 & 53 & 22 & 44 & 9 & 36 & 55 & 0 & 50 & 14 \\
\hline Jun & 0 & 29 & 29 & 47 & 33 & 19 & 0 & 36 & 26 & 0 & 0 & 29 \\
\hline Jul & 0 & 0 & 21 & 33 & 22 & 25 & 18 & 36 & 26 & 0 & 50 & 57 \\
\hline Aug & 20 & 14 & 17 & 47 & 56 & 13 & 36 & 50 & 29 & 25 & 25 & 43 \\
\hline Sep & 20 & 29 & 31 & 40 & 56 & 44 & 18 & 43 & 43 & 25 & 25 & 71 \\
\hline Oct & 0 & 0 & 21 & 53 & 56 & 63 & 18 & 29 & 19 & 25 & 25 & 29 \\
\hline Nov & 0 & 0 & 5 & 33 & 67 & 31 & 9 & 29 & 7 & 0 & 0 & 0 \\
\hline Dec & 0 & 0 & 5 & 7 & 0 & 50 & 18 & 0 & 0 & 0 & 0 & 57 \\
\hline
\end{tabular}

month did not occur until October and November, and this was restricted to the Duero and Tajo basins. In December, a southwards displacement of the hydrological response was observed, and this resulted in reinforcement of the November NAO influence across the southernmost basins of the Atlantic watershed. This occurred prior to the commencement of the highly active winter NAO period, when the IP was again completely under the influence of the NAO.

\subsection{Influence of the winter NAO throughout the year}

Figure 4 shows the spatial distribution of the correlations between the winter NAO index and the streamflows from March (the last month of winter) to the following November (the last month before the next winter) at each gauging station for the period 1945-2005. There was a clear carryover in the response of streamflow to the NAO conditions during winter, and this influence persisted throughout the year, particularly in the main watercourses. Significant correlations were found throughout IP, with the exception of the Mediterranean and Cantabrian coastal areas during March and April. The winter NAO influence decreased $(R \approx 0.35)$ during spring and summer, and was confined to the main rivers of the Duero, Tajo and Guadiana basins, and the headwaters of the Jucar River in the Iberian Range. This pattern remained stable during autumn, although with some variability: the correlations clearly decreased in the Ebro basin (particularly the headwaters), whereas there was an increased response in the headwaters of the highly regulated Tagus, Júcar and Guadiana basins.

\subsection{Streamflow anomalies during extreme NAO phases}

Figure 5 summarizes the streamflow anomalies recorded for each month of the year in the major basins during positive and negative NAO phases. Extreme positive NAO phases generally produced negative anomalies in all basins throughout the year. However, the moderate and uniform anomalies observed throughout the year in those basins showing low within-basin variability (including the Guadiana, Júcar, Segura and Ebro basins) is in contrast with the larger anomalies observed during winter in the Cantabrian, Duero, Guadalquivir, Mondego, Catalonian and Andalusian basins. The latter also showed greater sensitivity to extreme positive NAO phases during summer, and also greater withinbasin variability because of its intermittent and torrential regime.

During negative NAO phases the pattern described above was reversed, with positive anomalies occurring in all major basins. Nevertheless, marked differences were observed in the responses among basins, depending on their location within the Atlantic watershed or on the Mediterranean fringe. Negative phases of the NAO generated moderate streamflow anomalies in the Ebro, Júcar, Segura and Catalonian basins (Mediterranean watershed), with no major differences among months and seasons. In contrast, all the basins in the Atlantic watershed (Cantabrian, Miño, Duero, Tajo, Guadiana, Guadalquivir and Mondego basins) showed enhanced responses to negative phases during late winter and early spring, which stabilized during the remainder of the year.

Table 1 shows the percentage of gauging stations that registered significant differences between the average SSI anomalies generated during positive and negative NAO phases. It is noteworthy the high percentages $(>70 \%)$ of gauges in the large Atlantic basins (Duero, Tajo, Guadiana and Guadalquivir) showed significant differences during winter and early spring. Among these basins, those located in the south (the Guadiana and Guadalquivir basins) showed the greatest effects, with the entire basins showing significant differences in anomalies in three months during that period. The Andalusian basins showed a high percentage of significant differences between the streamflow anomalies generated by opposite NAO phases, even though they are within the Mediterranean watershed.

The PCA (Fig. 6) revealed three components in the spatiotemporal variability of streamflow anomalies during the 

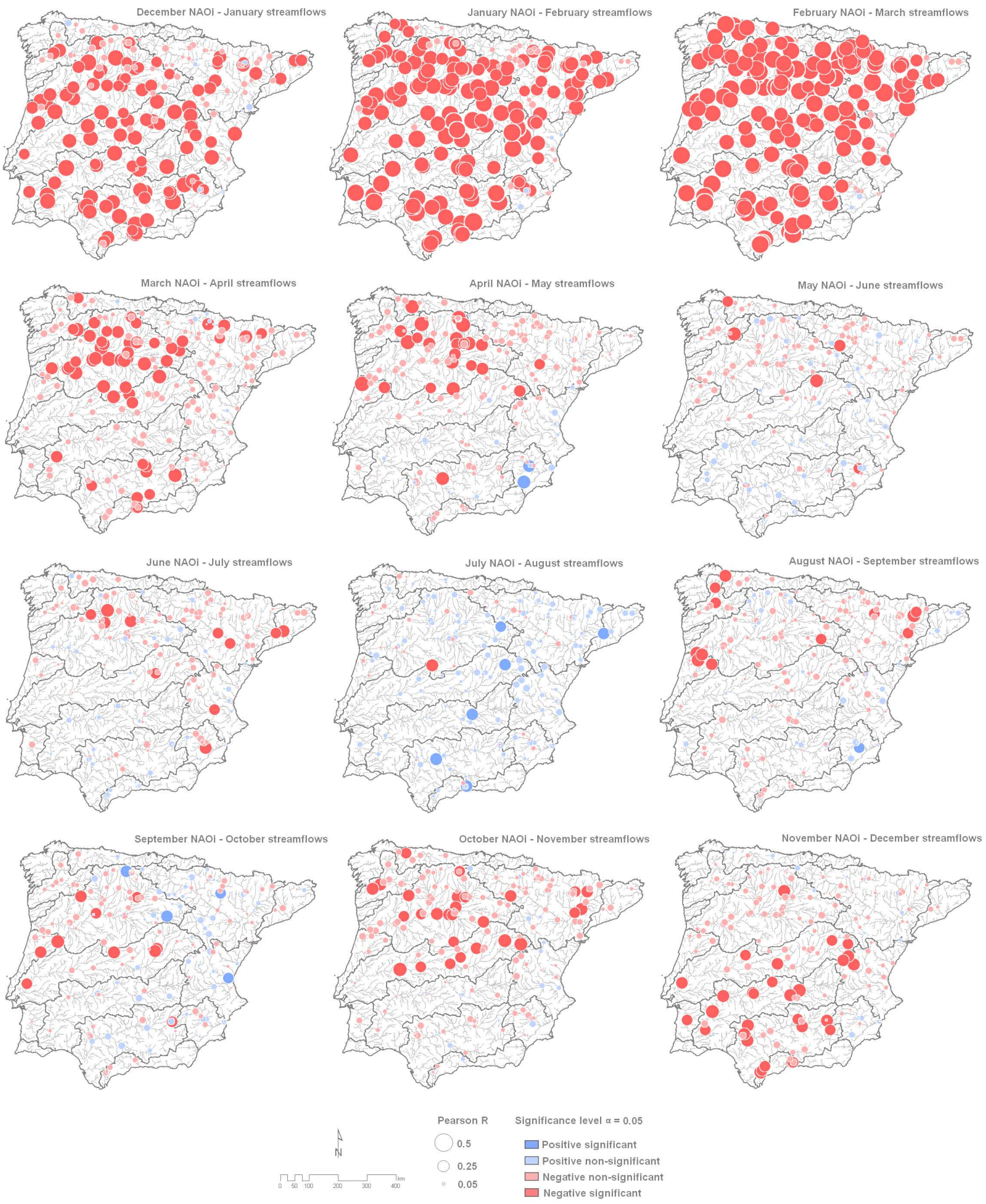

Fig. 3. Spatial distribution of the correlations between the monthly NAO index and the subsequent monthly SSI's. 

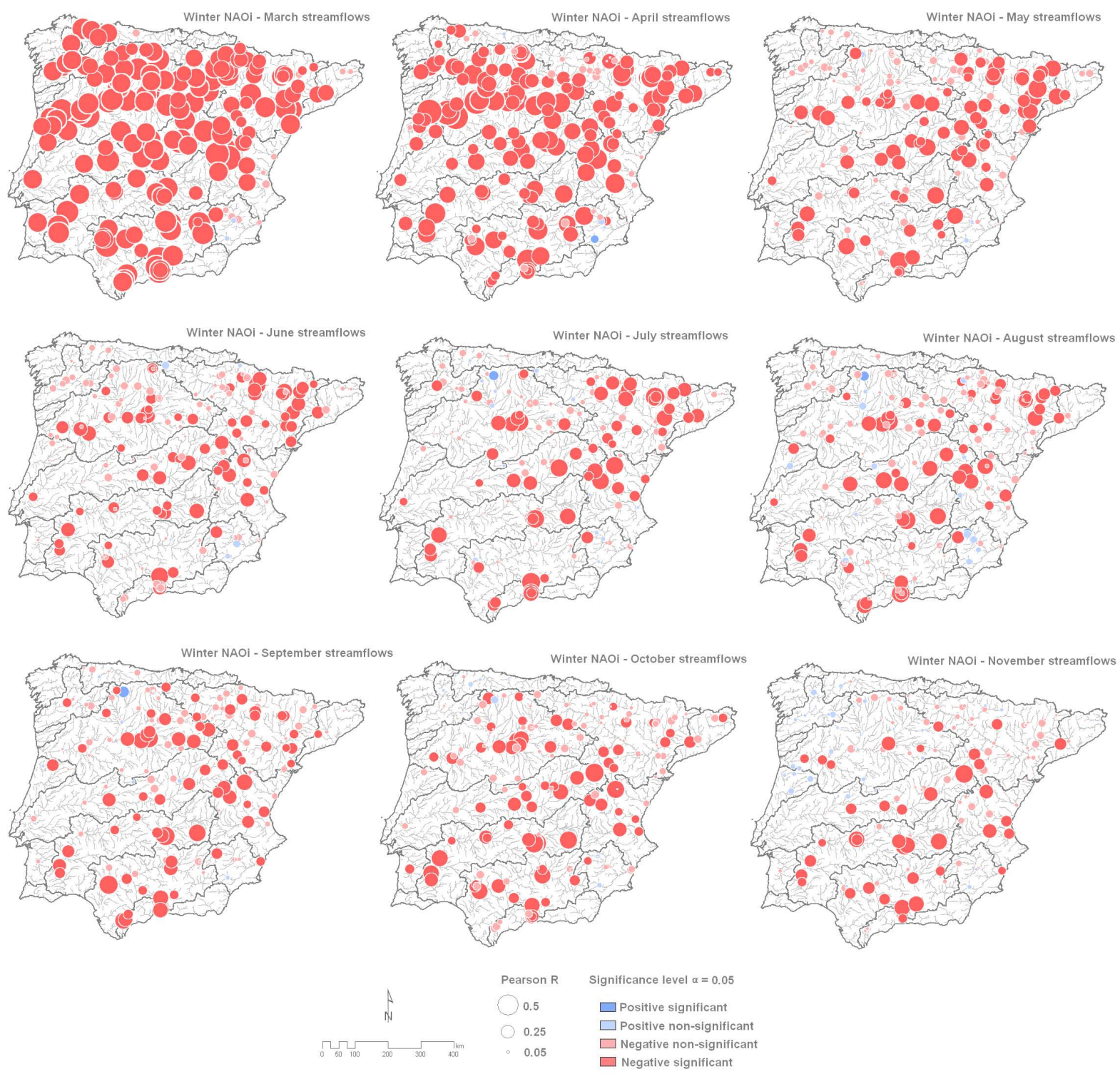

Fig. 4. Spatial distribution of the correlations between the Winter NAO index and the monthly SSI's.

extreme NAO phases. The first principal component explained almost $40 \%$ of the total variance, and showed the most general spatio-temporal pattern of streamflow anomalies. It was characterized by positive streamflow anomalies during negative NAO phases (and vice versa) in all months of the year, although the anomalies were enhanced during late spring and summer. The spatial extent of this pattern included the entire IP, although it was more related to the major river courses of the Atlantic watershed and the entire Mediterranean fringe. The second principal component explained $29 \%$ of the variance, and indicated large positive streamflow anomalies in winter and early spring and modest negative anomalies in summer during negative NAO phases. The influence of the negative NAO phases was very low, with a clear non-linear behavior in the response of streamflow to the NAO. This component mainly represented the Atlantic watershed.

The third principal component explained only $6.4 \%$ of the variance and it did not show a clear pattern related to the SSI anomalies in response to the positive and negative NAO phases. Nevertheless, this pattern was representative of some northeastern areas of the IP, where the correlation between the NAO and streamflow was quite low.

\subsection{Moving-window correlations}

To investigate the influence of the NAO on streamflow evolution, we first performed a moving-window correlation (21 yr) 

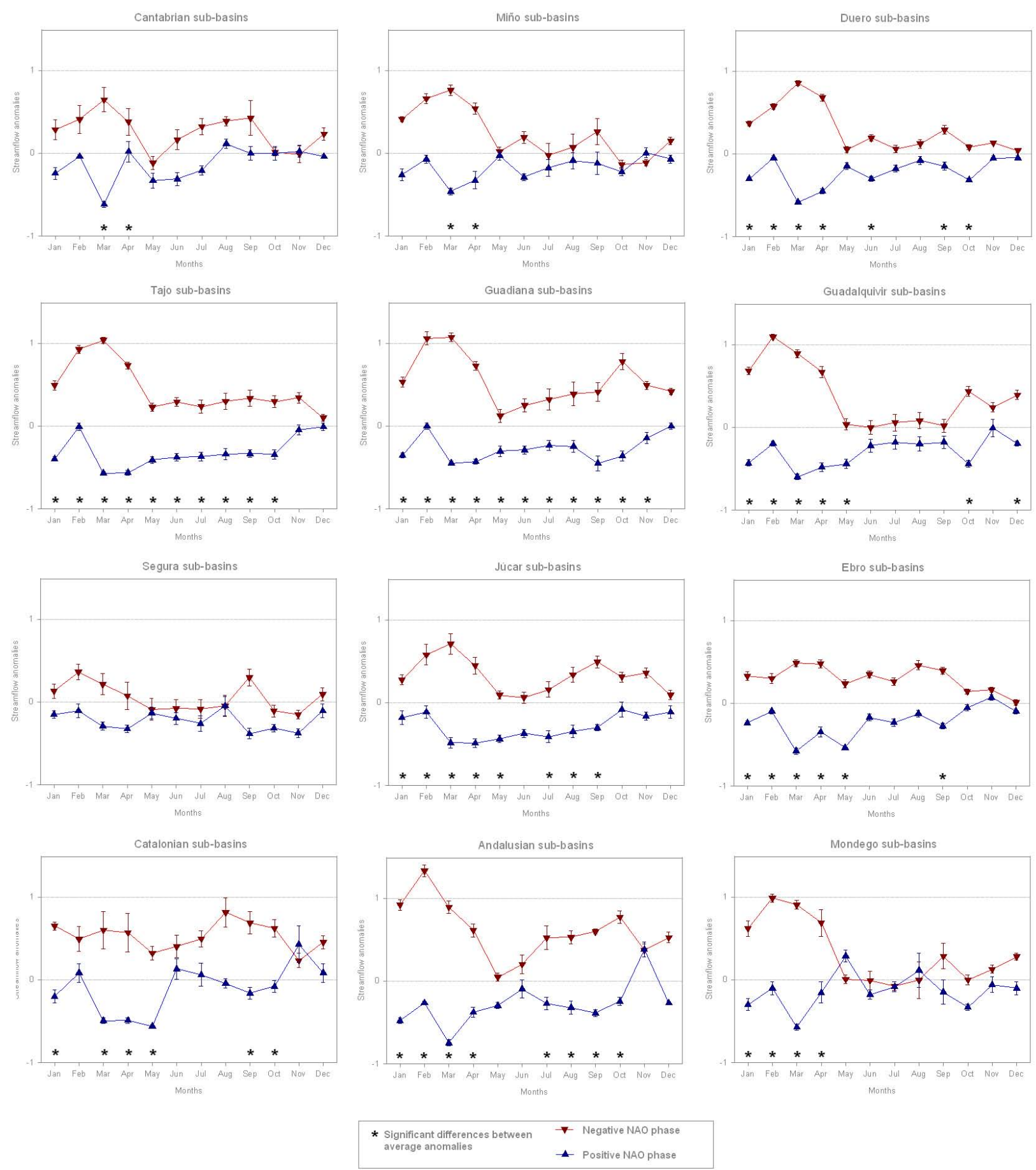

Fig. 5. Statistical summary of the streamflow anomalies registered during positive and negative winter NAO phases classified by major basins. Triangles represents the mean of the streamflow anomalies registered in every sub-basin gauge. Whiskers represents the mean's standard error. Asterisks depicted significant differences between mean positive and negative anomalies, obtained by means of the Wilcoxon Mann Whitney test. 

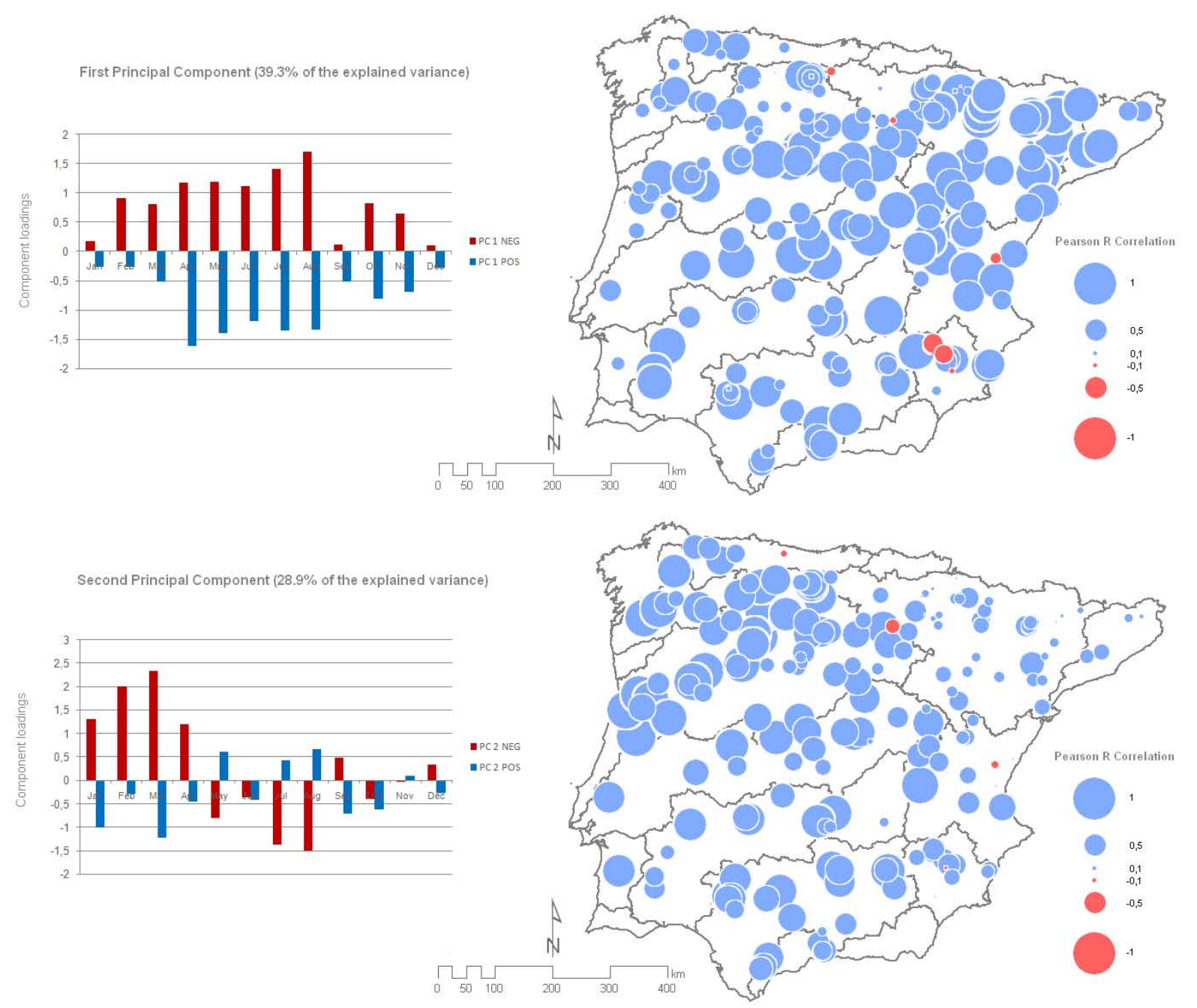

Third Principal Component ( $6.4 \%$ of the explained variance)

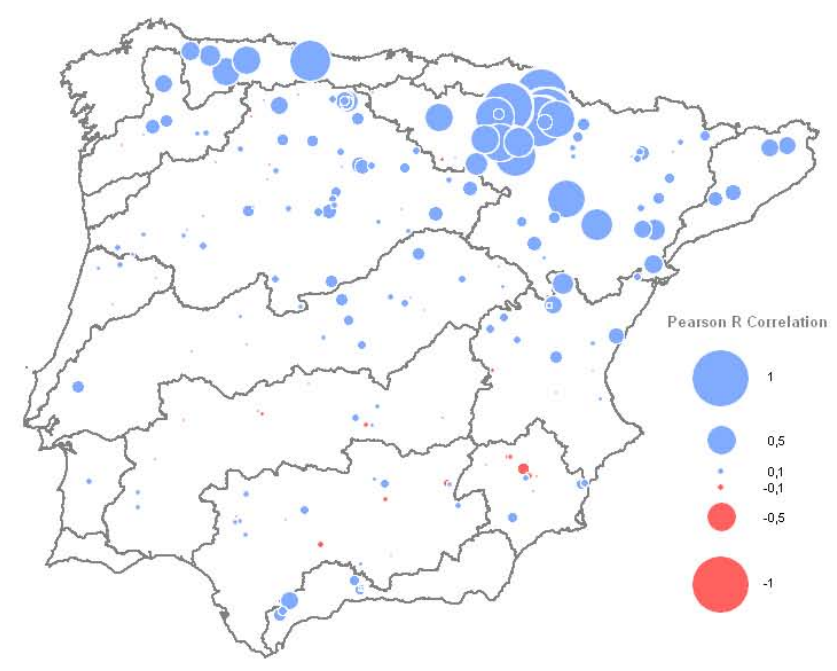

Fig. 6. The scores of the three first Principal Components extracted from the anomalies series during positive (blue bars) and negative (red bars) NAO phases (left column). Spatial distribution of the correlation coefficients between the scores of the Principal Components and the original anomalies registered at every gauging station (right column). 
analysis between the monthly Winter NAO index and the March SSI of each gauging station. A PCA was used to summarize the general temporal evolution of the NAO influence on streamflow. Figure 7 shows the temporal evolution of the three first principal components (left) and the correlations between their scores and the moving-window correlation series obtained for each gauging station (right). The first Principal Component explained approximately $28 \%$ of the variance. It was characterized by a low influence of the NAO influence on streamflow during the 1950s, 1960s and 1970s, and an enhanced response of streamflow to the NAO since the 1980s. Fitting this pattern were the Cantabrian basins, the Mondego basin, most of the Duero main course, the middle and upper Tajo and Guadalquivir basin tributaries, the majority of Júcar and Andalusian basins and some of the Pyrenean tributaries of the Ebro river. The second Principal component explained $23.8 \%$ of the variance. It was characterized by a strong NAO influence on streamflow during the 1960s and a stabilization of the response in recent years. The basins having this variability mode included the right bank Duero tributaries, the Tajo main course, much of the upper Ebro basin and the Segre river and its tributaries (Ebro basin).

The third Principal Component accounts for $16.7 \%$ of the explained variance. It presents a low response of the streamflows to the NAO during the 1950s and the 1960s, a enhanced response during the 1970s and a weakening of the influence to present. The sub-basins fitting this pattern are the headwaters of the Duero, Ebro and Tajo rivers, the Guadiana main course and the Guadalquivir lower reaches. These results show that in general the streamflow response to the NAO was highly variable in time, and that non-stationarity was the general pattern between 1945 and 2005.

\section{Discussion}

\subsection{The global patterns of the relationship streamflow and NAO}

Various factors control streamflow behavior, including water management, the melting of snow, and land cover changes, but precipitation plays a major role in explaining streamflow variability in both time and space. As a consequence, a generalized relationship has been found between NAO and streamflow across Europe, especially during winter (Shorthouse and Arnell, 1997; Dettinger and Díaz, 2000) and in the Mediterranean region (Cullen and DeMenocal, 2000; Cullen et al., 2002; Karabork et al., 2005; Kalayci and Kahya, 2006; Kucuk et al., 2009).

Many studies in the IP have related precipitation to the $\mathrm{NAO}$, and shown that the NAO is the major source of interannual variability, particularly in winter (Rodríguez-Puebla et al., 2001; Goodess and Jones, 2002). This relationship is negative, with highly significant values $(r<-0.6)$ in the western and central parts of the IP (Ulbrich et al., 1999;
Trigo, 2008) decreasing to the east along the Mediterranean fringe (Martín-Vide and Fernández, 2001). Based on this pattern, the NAO impacts on surface water resources in a number of basins have been analyzed in several studies. MoránTejeda et al. (2011) reported the response of sub-basins in the Duero catchment to the NAO, and showed generally negative streamflow anomalies during positive NAO phases in winter, and vice versa. Similar results were reported for the Tagus catchment in extreme NAO phases (López-Moreno et al., 2007). A more global approach that included the three main Atlantic catchments (Duero, Tagus and Guadiana) has shown similar results (Trigo et al., 2004). These results are all consistent with the general analyses presented in this report.

\subsection{Spatial and temporal variability}

We found that the response of Iberian streamflows to the NAO were not homogeneous in time or space. As noted previously, precipitation plays a major role in explaining hydrological variability, and because precipitation is highly dependent on the NAO, factors that influence the spatial extent of the NAO could affect river responses. Our findings suggest that orography, water storage strategies, snowmelt and latitudinal factors associated to the movement of pressure centers across the Atlantic Ocean may help explain the contrasting patterns observed in this study, as discussed below.

The spatial extent of the NAO influence on streamflow during winter and late autumn is largely determined by orography. The advance into the IP of southwesterly air masses associated with the NAO is facilitated by the gradual altitudinal increase and the smooth slopes of the lower Tagus, Guadiana and Guadalquivir valleys (Esteban et al., 2003). Although air masses progressively lose their humidity as they cross the IP, they are forced up by the topographic barrier to the east (the Cantabrian Range, the Iberian Ranges and the Betic systems), which separates the Atlantic and Mediterranean watersheds. Thus, the leeward sides of the mountain chains are less influenced by the NAO than the western part of the IP (Esteban-Parra et al., 1998; Muñoz-Díaz, 2003). This phenomenon is enhanced during autumn, when the NAO is less active, with a topographic shadow effect causing the depletion of humidity in air masses crossing the barrier, and a consequent decrease in the correlation values between the two watersheds. Orography may also explain why there was a significant correlation between the NAO and streamflow in the Pyrenean sub-basins during October and December, while in the other Mediterranean watersheds the correlations were not significant. Because of their north-south orientation the Pyrenean valleys act as humid corridors for the advance of air masses from the south. The mountainous topography induces their reactivation and generates orographic precipitation (Esteban et al., 2003).

We found an abrupt temporal transition from winter to spring and from summer to autumn in the NAO-streamflow 

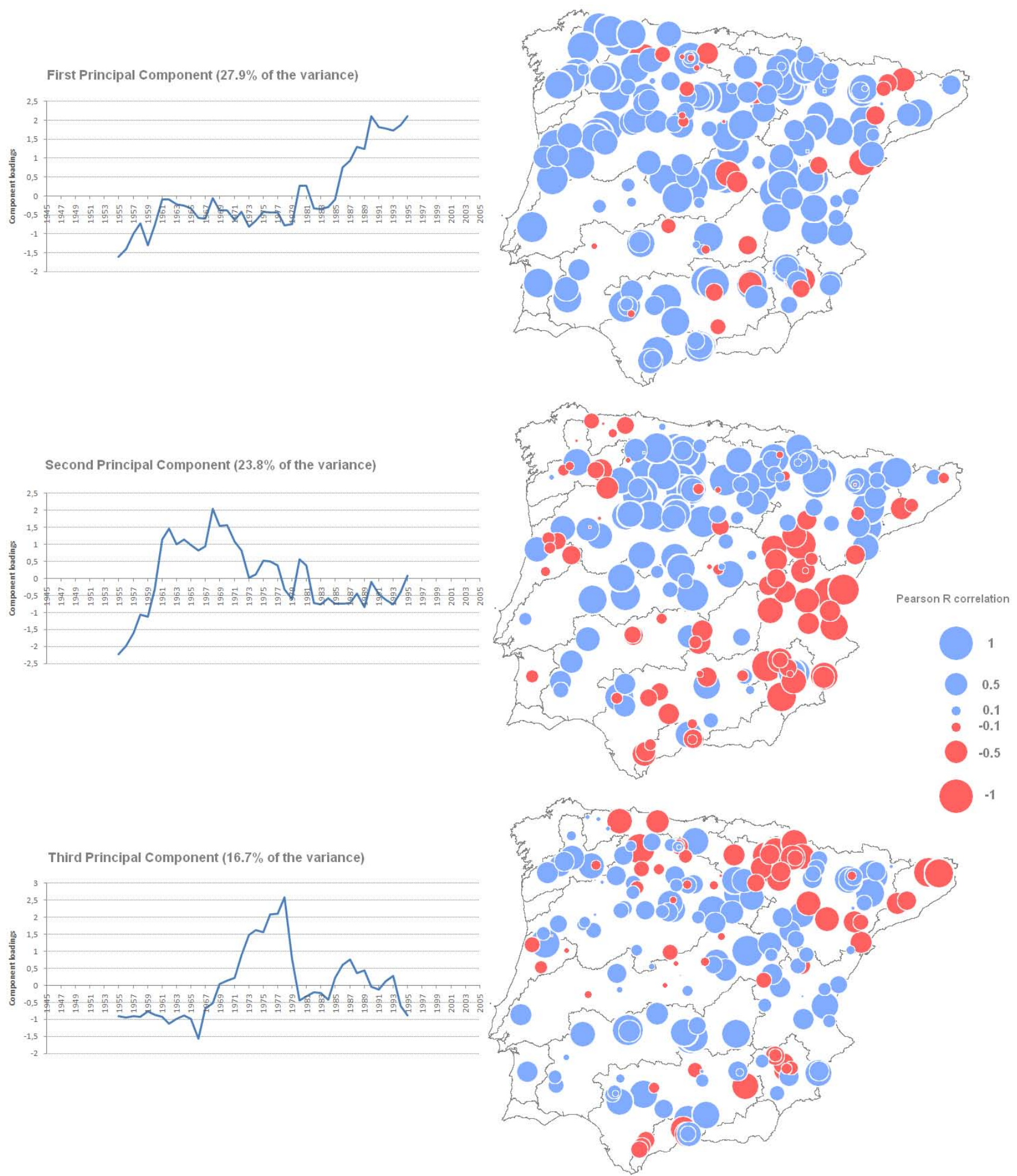

Fig. 7. The scores of the three first Principal Components extracted from the moving-window ( 21 yr) correlation series between the monthly Winter NAO index and the monthly March SSI's (left column). Spatial distribution of the correlation coefficients between the scores of the Principal Components and the original moving correlations between the monthly Winter NAO index and the monthly March SSI's obtained at every gauging station (right column). 
relationship between the non-lagged and the one-month lagged correlations, which can be explained in terms of water management and atmospheric phenomena. This was exemplified during April and early autumn. During winter and spring, management practices are focused mainly on storing water; this results in decreased water releases, and hence decreased river discharges downstream of dams (López-Moreno, 2007). The relationship between the NAO and streamflow in April was non-significant for the nonlagged correlation, while for the one-month lagged correlation the relationship was significant in catchments located to the northwest. This difference was probably caused by seasonal weakening of the NAO as a result of a change in the position of the pressure centers (Kingston et al., 2006a), but also as a consequence of water management strategies focused on storing water resources in dams. The inverse was true for the transition from summer to autumn. During October the relative movement of the pressure centers associated with the NAO (Kingston et al., 2006a) generates inflow from the Atlantic, initially in the northwest (Duero basin) during October. Subsequently, a southward displacement of the influence occurs, covering the southwest during November (Trigo et al., 2008) and reaching its maximum influence and spatial extent during winter.

The positive correlations between streamflow and the summer NAO, which were mainly significant during July, are in agreement with the recent findings of Bladé et al. (2010), who found significant positive correlations between precipitation and the NAO during July and August in the central sector of the IP. This relationship apparently occurs because the positive phase of the summer NAO is related to cool, wet and cloudy conditions in southern Europe and the Mediterranean region (Folland et al., 2008).

The water management strategy relies on a large number of dams impounding the majority of basins in the IP, which explains the multi-temporal lagged relationships between NAO, precipitation and stream flows. Water is stored in reservoirs during the rainy period (winter and spring) to meet the water demand during summer, which reduces streamflows downstream of the reservoirs during winter and spring. This explains the close relationship of summer and autumn streamflow to the previous winter NAO, especially in the southern basins with larger impoundment capacities (Tagus, $11012 \mathrm{hm}^{3}$; Guadiana, $8635 \mathrm{hm}^{3}$; and Guadalquivir, $8280 \mathrm{hm}^{3}$ ): the majority of those rivers with retention capacity exceeding the mean annual discharge for the study period showed a sustained response to the winter NAO during the rest of the year. The strong correlations between the winter NAO index and streamflows during May, June and July in the Pyrenean sub-basins reflect the importance of snow accumulation and melting processes in the Pyrenean rivers (López-Moreno and García-Ruiz, 2004), and the inertia that these processes induce in the runoff yield.

\subsection{The extreme phases of NAO and their relationships to stream flow}

The results of analysis of the streamflow response to extreme NAO phases were consistent with the other analyses. Streamflow anomalies during negative NAO phases were generally greater in magnitude than those during positive phases. This may be related to the physical properties of the catchments and their hydrological behavior. Because of the large amount of precipitation generated by extreme rainfall events associated with negative NAO phases, soils rapidly became saturated, and runoff produces a marked increase in river discharges (Morán-Tejeda, 2011). However, to guarantee water supply the water management strategies reduce the magnitude of the negative anomalies during positive NAO phases, generating more uniform streamflows, even during extreme dry periods.

Significant spatial differences were found between the Atlantic and Mediterranean basins. Winter positive anomalies in the Atlantic watershed were greater than those in the eastern basins adjacent to the Mediterranean Sea, but the intracatchment variability and streamflow anomalies during extreme NAO phases (both positive and negative) were greater in the Andalusian basins, which is related to their intermittent fluvial regimes, small basin areas and orography. The PCA revealed three different patterns of seasonality in streamflow anomalies during positive and negative NAO phases, with a clear spatial distribution. The general pattern depicts large streamflow anomalies during both positive and negative NAO phases, that spread throughout the whole year and along the entire IP and may be related to the general westerly circulation. The second pattern shows anomalies restricted mainly to winter months, when the NAO is more active, and solely during negative NAO phases. This pattern is observed for all river basins of the Atlantic watershed and reveals the importance of the shadow effect produced by the mountainous chains which divides the IP into the Atlantic and the Mediterranean watershed, blocking the advance of the humid flows coming from the Atlantic. The third pattern does not show a clear seasonality in the distribution of anomalies but it presents a well-defined spatial distribution, which may be related to northern flows coming from the Gulf of Biscay. These could be associated to the positive phases of the Western Mediterranean Oscillation as previously stated by Martín-Vide and López Bustins (2006).

\subsection{Non-stationarity analysis}

The non-stationarity analysis highlighted three main patterns in the evolution of the NAO impact on streamflows over the last years. The first involved an increase in the impact of the NAO on streamflows since the 1980s in most parts of the IP, although it is more pronounced in the northwestern sector. These findings are similar to those of VicenteSerrano and López-Moreno (2008), who reported an increase 
in the magnitude of negative correlations between the NAO and precipitation in southern Europe, which was closely related to shifts in the location of the Atlantic pressure centers. The second pattern involved a decrease in the correlations between the NAO and streamflows in the right bank Duero tributaries, the Tajo main course, much of the upper Ebro basin and the Segre river and its tributaries (Ebro basin). These basins have been subject to increased regulation/impoundment capacity, aimed at reducing the impacts of lack of precipitation and meet the demand for irrigating purposes. This increased capacity may explain the decreased sensitivity of streamflow to the NAO variability during extreme phases. The decrease in the sensitiveness to the NAO of the basins correlated with the Third Principal Component reported since the 1980s may be also related to the increased regulatory capacity in the river courses since the eighties. However, as-yet unresolved uncertainties remain in relation to this recently completed preliminary analysis, suggesting the need for more detailed investigations.

\subsection{Uncertainties}

Several uncertainties remain concerning the future behavior of streamflow in response to the NAO, and these should be the subject of future research. The dependence of streamflow in Iberian rivers on the NAO has been demonstrated, as has a persistent positive NAO trend during the past three decades (Visbeck et al., 2001; Osborn, 2004). These factors suggest that the maintenance of ecological river flows, riparian ecosystems, and the long-term supply of water for irrigation and leisure are at risk. Projections for the 21th century indicate a trend to positive phases of the NAO, and thus a trend of decreasing precipitation (Rodriguez-Puebla and Nieto, 2010). Moreover, the scenarios show stable correlations between the NAO and precipitation in southern Europe (Vicente-Serrano and López-Moreno, 2008). If these predictions are realized, the implications for surface water resources in the IP become worse, as water management strategies and water regulation capacity appear to be inadequate to address the changing NAO impacts on the surface hydrology of the IP.

\section{Conclusions}

This study demonstrated the impact of the NAO on the streamflows of Iberian rivers. A significant response of streamflows to the evolution of the NAO was observed across the entire IP during winter and autumn, particularly in the Atlantic watershed. The effect was greater when the NAO conditions in the previous month were considered. Persistence of the winter NAO conditions throughout the year was also observed, with some spatial variations, mainly in highly regulated basins. We also showed positive streamflow anomalies during extreme negative NAO phases, and vice versa.
We conclude that since the 1970s the impact of the NAO has strengthened in some basins of the IP, and weakened in others.

Acknowledgements. We would like to thank the Centro de Estudios Hidrográficos (CEDEX), Sistema Nacional de Informaçâo de Recursos Hídricos (SNIRH), Agència Catalana de l'Aigua, Agencia Andaluza del Agua and Augas de Galicia for providing the hydrological data used in this study. We also want to thank to the Climate Research Unit for the North Atlantic Oscillation data. This work has been supported by a pre-doctoral fellowship by the Aragón Government (Spain), and by the research projects CGL2006-11619/HID and CGL2008-01189/BTE, financed by the Spanish Commission of Science and Technology and FEDER, EUROGEOSS (FP7-ENV-2008-1-226487), ACQWA (FP7-ENV2007-1-212250) financed by the VII Framework Programme of the European Commission, and "La nieve en el Pirineo Aragonés y su respuesta a la variabilidad climática" financed by "Obra Social La Caixa" and the Aragón Government.

Edited by: C. de Michele

\section{References}

Arroyo-Ilera, F.: Territorio, tecnología y capital. La regulación hidroeléctrica de los ríos españoles (1900-1970), Treballs de la Societat Catalana de Geografía, 63, 39-70, 2007.

Barlow, M., Nigam, S., and Berbery, E. H.: ENSO, Pacific Decadal Variability, and U.S. Summertime Precipitation, Drought, and Stream Flow, J. Climate, 14, 2105-2128, 2001.

Barros, V., Chamorro, L., Coronel, G., and Baez, J.: The Major Discharge Events in the Paraguay River: Magnitudes, Source Regions, and Climate Forcings, J. Hydrometeorol., 5, 1161-1170, 2004.

Beranová, R. and Huth, R.: Time variations of the effects of circulation variability modes on European temperature and precipitation in winter, Int. J. Climatol., 28: 139-158, 2008.

Berga-Casafont, L.: Presas y embalses en la España del siglo XX, Revista de Obras Públicas, 3438, 37-40, 2003.

Bierkens, M. F. P. and Van Beek, L. P. H.: Seasonal Predictability of European Discharge: NAO and Hydrological Response Time, J. Hydrometeorol., 10, 953-968, 2009.

Bladé, I. and Fortuny, D.: Connections between the Summer North Atlantic Oscillation (SNAO) and drying in the Mediterranean Region, oral communication in ESF-MedCLIVAR Workshop on Hydrological, socioeconomic and ecological impacts of the North Atlantic Oscillation in the Mediterranean Region, Zaragoza (Spain), 2010.

Bower, D., Hannah, D. M., and McGregor, G. R.: Techniques for assessing the climatic sensitivity of river flow regimes, Hydrol. Process., 18, 2515-2543, 2004.

Brito-Castillo, L., Douglas, A. V., Leyva-Contreras, A., and LluchBelda, D.: The effect of large-scale circulation on precipitation and streamflow in the gulf of California continental watershed, Int. J. Climatol., 23, 751-768, 2003.

Bradbury, J. A., Dingman, S. L., and Keim, B. D.: New England drought and relations with large scale atmospheric circulation patterns, J. Am. Water Resour. Ass., 38(5), 1287-1299, 2002. 
Burn, D.: Climatic influences on streamflow timing in the headwaters of the Mackenzie River Basin, J. Hydrol., 352, 225-238, 2008.

Camilloni, I. and Barros, V.: The Paraná River Response to El Niño 1982-83 and 1997-98 Events, J. Hydrometeorol., 1, 412-430, 2000.

Castro-Díez, Y., Pozo-Vázquez, D., Rodrigo, F. S., and Esteban-Parra, M. J.: NAO and winter temperature variability in southern Europe, Geophys. Res. Lett., 29(8), 1160, doi:10.1029/2001GL014042, 2002.

Cullen, H. M. and deMenocal, P. B.: North Atlantic influence on Tigris-Euphrates streamflow, Int. J. Climatol., 20, 853-863, 2000.

Cullen, H. M., Kaplan, A., Arkin, P. A., and Demenocal, P. B.: Impact of the North Atlantic Oscillation on the middle eastern climate and streamflow, Clim. Change, 55, 315-338, 2002.

De-Castro, M., Martín-Vide, J., and Alonso, S.: El clima de España: pasado, presente y escenarios de clima para el siglo XXI. Impactos del cambio climático en España, Ministerio Medio Ambiente, Madrid, 2005.

Dettinger, M. D. and Diaz, H. F.: Global characteristics of stream flow seasonality and variability, J. Hydrometeorol., 1, 289-310, 2000.

Esteban, P., Soler, X., Prohom, M., and Planchon, O.: La distribución de la precipitación a través del índice NAO, El efecto del relieve a escala local: el Pirineo Oriental, in: El Clima y el Agua, Publicaciones de la Asociación Española de Climatología, Serie A, 3, 25-34, 2003.

Esteban-Parra, M. J., Rodrigo, F. S., and Castro-Díez, Y.: Spatial and temporal patterns of precipitation in Spain for the period 1880-1992, Int. J. Climatol., 18, 1557-1574, 1998.

Folland, C. K., Knight, J., Linderholm, H. W., Fereday, D., Ineson, S., and Hurrel, J. W.: The Summer North Atlantic Oscillation: Past, Present, and Future, J. Climate, 22, 1082-1103, 2008.

Gámiz-Fortis, S. R., Esteban-Parra, M. J., Trigo, R. M., and CastroDíez, Y.: Potential predictability of an Iberian river flow based on its relationship with previous winter global SST, J. Hydrol., 385, 143-149, 2010.

González-Hidalgo, J. C., De Luis, M., Raventós, J., and Sánchez, J. R.: Spatial distribution of seasonal rainfall trends in a western Mediterranean area, Int. J. Climatol., 21, 843-860, 2001.

González-Hidalgo, J. C., López-Bustins, J. A., Stepánek, P., MartínVide, J., and De Luis, M.: Monthly precipitation trends on the Mediterranean fringe of the Iberian Peninsula during the secondhalf of the twentieth century (1951-2000), Int. J. Climatol., 29(10), 1415-1429, 2009.

González-Hidalgo, J. C., Brunetti, M., and De-Luis, M.: A new tool for monthly precipitation analysis in Spain: MOPREDAS database (monthly precipitation trends December 1945-November 2005), Int. J. Climatol., 31(5), 715-731, doi:10.1002/joc.2115, 2010.

Goodess, C. M. and Jones, P. D.: Links between circulation and changes in the characteristics of Iberian rainfall, Int. J. Climatol., 22, 1593-1615, 2002.

Hatzaki, M., Flocas, H. A., Asimakopoulos, D. N., and Maheras, P.: The eastern Mediterranean teleconnection pattern: identification and definition, Int. J. Climatol., 27, 727-737, 2007.

Hurrell, J.: Decadal trends in the North Atlantic Oscillation: regional temperatures and precipitation, Science, 269, 676-679,
1995.

Hurrell, J. W. and Van Loon, H.: Decadal variations in climate associated with the North Atlantic Oscillation, Clim. Change, 36, 301-326, 1997.

Hurrell, J. W., Kushnir, Y., Ottersen, G., and Visbeck, M.: An overview of the North Atlantic Oscillation. The North Atlantic Oscillation: Climate Significance and Environmental Impact, Geophysical Monograph, Amer. Geophys. Union, 134, 1-36, 2003.

Iglesias, A., Estrela, T., and Gallart, F: 7. in: Impactos sobre los recursos hídricos, Evaluación preliminar de los impactos en España por efecto del cambio climático, edited by: Moreno Rodríguez, J., Ministerio de Medio Ambiente y Universidad de Castilla-La Mancha, 2005.

Jones, P. D., Jónsson, T., and Wheeler, D.: Extension to the North Atlantic Oscillation using early instrumental pressure observations from Gibraltar and south-west Iceland, Int. J. Climatol., 17, 1433-1450, 1997.

Kalayci, S. and Kahya, E.: Assessment of streamflow variability modes in Turkey: 1964-1994, J. Hydrol., 324, 163-177, 2006.

Karabörk, M. C., Kahya, E., and Karaca, M.: The influences of the Southern and North Atlantic Oscillations on climatic surface variables in Turkey, Hydrol. Process., 19, 1185-1211, 2005.

Kingston, D. G., Lawler, D. M., and McGregor, G. R.: Linkages between atmospheric circulation, climate and river flow in the northern North Atlantic: research prospects, Prog. Phys. Geogr., 30, 143-174, 2006a.

Kingston, D. G., McGregor, G. R., Hannah, D. M., and Lawler, D. M.: River flow teleconnections across the northern North Atlantic region, Geophys. Res. Lett., 33, 1-5, 2006 b.

Krasovskaia, I., Arnell, N. W., and Gottschalk, L.: Flow regimes in northern and western Europe: development and application of procedures for classifying flow regimes, in: Flow Regimes from International Experimental and Network Data (FRIEND), IAHS, 221, 185-192, 1994.

Kücük, M., Kahya, E., Cengiz, T. M., and Karaca, M.: North Atlantic Oscillation influences on Turkish lake levels, Hydrol. Process., 23, 893-906, 2009.

Lavers, D., Prudhome, C., and Hannah, D. M.: Large-scale climatic influences on precipitation and discharge for a British river basin, Hydrol. Process., 24(18), 2555-2563, doi:10.1002/hyp.7668, 2010.

López-Bustins, J. A., Martín-Vide, J., and Sánchez-Lorenzo, A.: Iberia winter rainfall trends based upon changes in teleconnection and circulation patterns, Glob. Planet. Change, 63, 171-176, 2008.

López-Moreno, J. I. and García-Ruiz, J. M.: Influence of snow accumulation and snowmelt on streamflow in the central Spanish Pyrenees, Hydrol. Sci. J., 49, 787-802, 2004.

López-Moreno, J. I. and Vicente-Serrano, S. M.: Positive and negative Phases of the Wintertime North Atlantic Oscillation and Drought ocurrence over Europe: a multitemporal-scale approach, J. Climate, 21, 1220-1241, 2008.

López-Moreno, J. I., Beguería, S., Vicente-Serrano, S. M., and García-Ruiz, J.M.: Influence of the North Atlantic Oscillation on water resources in central Iberia: Precipitation, streamflow anomalies, and reservoir management strategies, Water Resour. Res., 43, W09411, doi:10.1029/2007WR005864, 2007.

Lorenzo-Lacruz, J., Vicente-Serrano, S. M., López-Moreno, J. I., 
Morán-Tejeda, E., and Zabalza, J.: Recent trends in Iberian streamflows (1945-2005), J. Hydrol., in review, 2010.

Maity, R. and Kumar, N.: Hydroclimatic influence of large-scale circulation on the variability of reservoir inflow, Hydrol. Process., 23, 934-942, 2009.

Martín-Vide, J. and Fernández, D.: El índice NAO y la precipitación mensual en la España peninsular, Investigaciones Geográficas, 26, 41-58, 2001.

Martín-Vide, J. and López-Bustins, J. A.: The Western Mediterranean Oscillation and rainfall in the Iberian Peninsula, Int. J. Climatol., 26, 1455-1475, 2006.

Massei, N., Laignel, B., Deloffre, J., Mesquita, J., Motelay, A., Lafite, R., and Durand, A.: Long-term hydrological changes of the Seine River flow (France) and their relation to the North Atlantic Oscillation over the period 1950-2008, Int. J. Climatol., 30(14), 2146-2154, doi:10.1002/joc.2022, 2009.

Morán-Tejeda, E., López-Moreno, I., Ceballos-Barbancho, A., and Vicente-Serrano, S. M.: Evaluating Duero's basin (Spain) response to the NAO phases: spatial and seasonal variability, Hydrol. Process., 25(8), 1313-1326, 2011.

Muñoz-Díaz, D. and Rodrigo, F. S.: Impacts of the North Atlantic Oscillation on the probability of dry and wet winters in Spain, Clim. Res., 27, 33-43, 2004.

Osborn, T. J.: Simulating the winter North Atlantic Oscillation: the roles of internal variability and greenhouse gas forcing, Clim. Dynam., 22, 605-623, 2004.

Osborn, T. J., Brifa, K. R., Tett, S. F. B., Jones, P. D., and Trigo, R. M.: Evaluation of the North Atlantic Oscillation as simulated by a coupled climate model, Clim. Dynam., 15, 685-702, 1999.

Pekarova, P. and Pekar, J.: Teleconnections of AO, NAO, SO and QBO with interannual streamflow fluctuation in the Hron Basin, J. Hydrol. Hydromech., 52, 279-290, 2004.

Phillips, I. D., McGregor, G. R., Wilson, C. J., Bower, D., and Hannah, D. M.: Regional climate and atmospheric circulation controls on the discharge of two British rivers, 1974-97, Theor. Appl. Climatol., 76, 141-164, 2003.

Pozo-Vázquez, D., Esteban-Parra, M. J., Rodrigo, F. S., and CastroDíez, Y.: An analysis of the variability of the North Atlantic Oscillation in the time and the frequency domains, Int. J. Climatol., 20, 1675-1692, 2000.

Preisendorfer, R. W.: Principal Component Analysis in Meteorology and Oceanography, Elsevier, New York, 425 pp., 1988.

Qian, B., Corte-Real, J., and Xu, H.: Is the North Atlantic Oscillation the most important atmospheric pattern for precipitation in Europe?, J. Geophys. Res., 105, 901-911, 2000.

Rimbu, N., Boroneant, C., Buta, C., and Dima, M.: Decadal variability of the Danube river flow in the lower basin and its relation with the North Atlantic Oscillation, Int. J. Climatol., 22, 11691179, 2002.

Rodriguez-Puebla, C., Encinas, A. H., Nieto, S., and Garmendia, J.: Spatial and temporal patterns of annual precipitation variability over the Iberian Peninsula, Int. J. Climatol., 18, 299-316, 1998.

Rodríguez-Puebla, C. and Nieto, S.: Trends of precipitation over the Iberian Peninsula and the North Atlantic Oscillation under climate change conditions, Int. J. Climatol., 30, 1807-1815, 2010.

Rodwell, M. J., Rowell, D. P., and Folland, C. K.: Oceanic forcing of the wintertime North Atlantic Oscillation and European climate, Nature, 398, 320-323, 2002.
Shorthouse, C. A. and Arnell, N. W.: Spatial and temporal variability in European river flows and the North Atlantic oscillation, in: Regional Hydrology - Concepts and models for sustainable water management, IAHS, 1997.

Stahl, K. and Demuth, S.: Linking streamflow drought to the occurrence of atmospheric circulation patterns, Hydrol. Sci. J., 44, 467-482, 1999.

Stepánek, P.: AnClim - software for time series analyses, Dept. of Geography, Fac. of Sciences, MU, Brno, 2005.

Trigo, R. M.: Quantifying the Impact of the North Atlantic Oscillation on Western Iberia, in: geoENV VI - Geostatistics for Environmental Applications, 235-246, 2008.

Trigo, R. M., Osborn, T. J., and Corte-Real, J. M.: The North Atlantic Oscillation influence on Europe: climate impacts and associated physical mechanisms, Clim. Res., 20, 9-17, 2002.

Trigo, R. M., Pozo-Vázquez, D., Osborn, T. J., Castro-Díez, Y., Gámiz-Fortis, S., and Esteban-Parra, M. J.: North Atlantic Oscillation influence on precipitation, river flow and water resources in the Iberian Peninsula, Int. J. Climatol., 24, 925-944, 2004.

Ulbrich, U., Christoph, M., Pinto, J., and Corte-Real, J.: Dependence of winter precipitation over Portugal on NAO and baroclinic wave activity, Int. J. Climatol., 19, 379-390, 1999.

Uvo, C.: Analysis and regionalization of northern European winter precipitation based on its relationship with the North Atlantic Oscillation, Int. J. Climatol., 23, 1185-1194, 2003.

Vicente-Serrano, S. M. and López-Moreno, J. I.: Differences in the non-stationary influence of the North Atlantic Oscillation on European precipitation under different scenarios of greenhouse gas concentrations, Geophys. Res. Lett., 35, 1-6, 2008.

Vicente-Serrano, S. M., Trigo, R. M., López-Moreno, J. I., Liberato, M. L. R., Lorenzo-Lacruz, J., Beguería, S., Morán-Tejeda, E., and El Kenawy, A.: The 2010 extreme winter North Atlantic Oscillation in Iberian precipitation: anomalies, driving mechanisms and future projections, Clim. Res., 46(1), 51-65, 2011.

Vicente-Serrano, S. M., López-Moreno, J. I., Beguería, S., LorenzoLacruz, J., Azorín-Molina, C., and Morán-Tejeda, E.: Accurate computation of a streamflow drought index, J. Hydrol. Eng., doi:10.1061/(ASCE)HE.1943-5584.0000433, 2011.

Visbeck, M. H., Hurrel, J. W., Polvani, L., and Cullen, H. M.: The North Atlantic Oscillation: Past, present and future, Proc. Nat. Ac. Soc., 98(23), 12876-12877, doi:10.1073/pnas.231391598, 2001.

Ward, P. J., Beets, W., Bouwer, L. M., Aerts, J. C. J. H., and Renssen, H.: Sensitivity of river discharge to ENSO, Geophys. Res. Lett, 37, L12402, doi:10.1029/2010GL043215, 2010.

Wilby, R.: Seasonal Forecasting of River Flows in the British Isles Using North Atlantic Pressure Patterns, Water Environ. J., 15, 56-63, 2001.

White, D., Richman, H., and Yarnal, B.: Climate regionalization and rotation of principal components, Int. J. Climatol., 11, 1-25, 1991.

Xue, Z., Liu, P. J., and Ge, Q.: Changes in hydrology and sediment delivery of the Mekong River in the last 50 years: connection to damming, monsoon, and ENSO, Earth Surf. Proc. Land., 36(3), 296-308, doi:10.1002/esp.2036, 2010.

Zorita, E., Kharin, V., and Von Storch, H.: The atmospheric circulation and sea surface temperature in the North Atlantic area in winter: Their interaction and relevance for Iberian precipitation, J. Climate, 5, 1097-1108, 1992. 